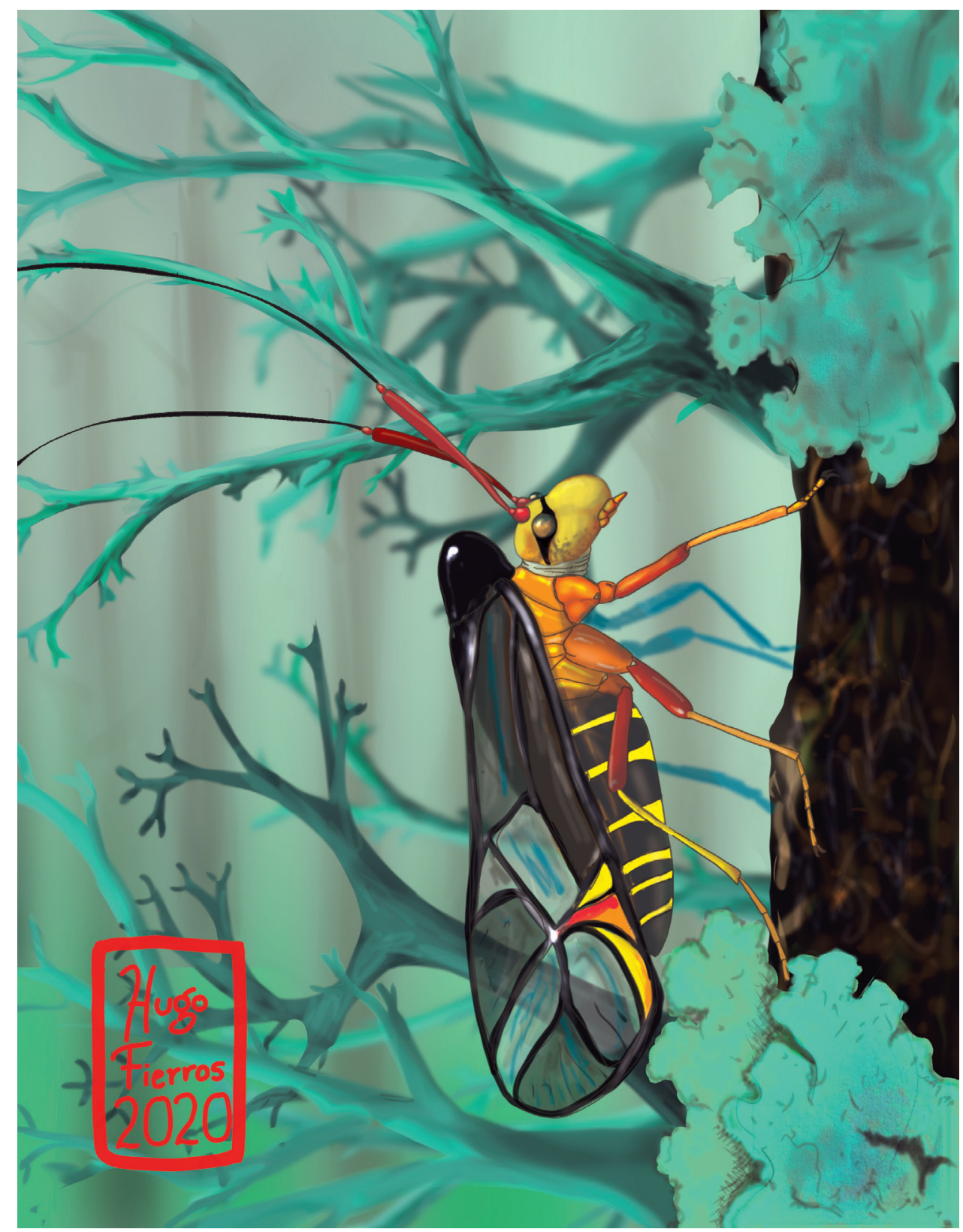

Dugesiana, Año 27, No. 2, julio 2020-diciembre 2020 segundo semestre de 2020), es una publicación semestral, editada por la Universidad de Guadalajara, a través del Centro de Estudios en Zoología, por el Centro Universitario de Ciencias Biológicas y Agropecuarias. Camino Ramón Padilla Sánchez \# 2100, Nextipac, Zapopan, Jalisco, Tel. 37771150 ext. 33218, http://148.202.248.171/dugesiana/index.php/DUG/index, glenusmx@gmail.com. Editor responsable: José Luis Navarrete-Heredia. Reserva de Derechos al Uso Exclusivo 04-2009-062310115100203, ISSN: 2007-9133, otorgados por el Instituto Nacional del Derecho de Autor. Responsable de la última actualización de este número: José Luis Navarrete-Heredia, Editor y Ana Laura González-Hernández, Asistente Editorial. Fecha de la última modificación 1 de julio 2020, con un tiraje de un ejemplar.

Las opiniones expresadas por los autores no necesariamente reflejan la postura del editor de la publicación.

Queda estrictamente prohibida la reproducción total o parcial de los contenidos e imágenes de la publicación sin previa autorización de la Universidad de Guadalajara. 


\title{
New species of Loneura Navas, 1927 (Insecta: Psocodea: 'Psocoptera': Ptiloneuridae) from Peru
}

\author{
Nueva especie de Loneura Navas, 1927 (Insecta: Psocodea: 'Psocoptera': Ptiloneuridae) de Perú \\ Ranulfo González Obando y Nancy Carrejo Gironza \\ Departamento de Biología, Facultad de Ciencias Naturales y Exactas, Universidad del Valle, Santiago de Cali, \\ COLOMBIA. ranulfo.gonzalez@correounivalle.edu.co; nancy.carrejo@correounivalle.edu.co
}

\begin{abstract}
We here describe and illustrate one new species of Loneura, based on specimens recently collected in natural areas of Peru. The new species is assigned to the infrageneric group II. This is the second species of this genus registered for this country. The number of species of Loneura is raised to 36 .
\end{abstract}

Key words: Taxonomy, Epipsocetae, South America.

\section{RESUMEN}

A partir de especímenes recientemente recolectados en áreas naturales de Perú, se describe e ilustra una nueva especie de Loneura. La nueva especie es asignada al grupo infragenérico II. Esta es la segunda especie de este género registrada para este país. El número de especies de Loneura se eleva a 36.

Palabras claves: Taxonomía, Epipsocetae, Suramérica.

In the genus Loneura Navás there are included 35 species (Gonzalez et al. 2020), which have been the result of explorations that have been made for the last ten years. Until 2011, only 13 species were known in Loneura, but in the last nine years there has been a significant increase in the number of species described. Garcia Aldrete et al. (2011 a, b) described four Colombian species; subsequently, Mendivil et al. (2017) described three additional species. More recently Moura Lima et al. (2019) described another from Brazil and Gonzalez et al. (2020) described 14 new species from Colombia, completing the total of 35 species known. Nevertheless some species found in Brazil, Ecuador, Mexico and Peru, remain undescribed to date (Gonzalez et al. 2020). As a result of psocidos samplings in natural areas of Peru, another species of Loneura was found, this is the second species of this genus that is registered in this country. In this writing this species is described and illustrated.

\section{MATERIAL AND METHODS}

Collection and preservation. The specimens were collected with a LED light trap. Two specimens were available for study, one of them was dissected in $80 \%$ ethanol, and their parts were mounted on slides in Canada balsam following standard procedures (see Gonzalez et al. 2011). Color was recorded from whole specimens, observed in $80 \%$ ethanol under a dissecting microscope illuminated with cold white light at 50x. Measurements (given in $\mu \mathrm{m}$ ) of parts on the slides (head, right wings and legs and genitalia), were taken with a micrometer, mounted on a Nikon Eclipse Ci microscope.
Abbreviations of parts measured are as follows: $\mathrm{H}$ : head median length (in dorsal view); MxW: maximum width of head capsule; Mx2, Mx4: length of second and fourth segment of right maxillary palpus, f1...fn: lengths of flagellomeres 1 ...n of right antenna, IO, D and d, respectively: minimum distance between compound eyes, antero-posterior diameter and transverse diameter of right compound eye, all in dorsal view of head; FW and HW: lengths of fore- and hind- wings; W: forewing width; lp: pterostigma length; wp: pterostigma width; w: hindwing width; al: areola postica length; ah: areola postica height; F, T, t1-t2: lengths of femur, tibia and tarsomeres 1-2 of right hind leg, ctt 1 : number of ctenidiobothria on $\mathrm{t} 1$ of right hind leg. Besides, ratios of head and wings were taken: $\mathrm{H} / \mathrm{MxW}$; PO: d/D; IO/d; FW/W; HW/w; lp/wp; al/ah (see González et al., 2011). The illustrations were made from digital photographs, taken with a Canon T5i camera and Helicon Focus program, processed in Clip Studio Paint vector graphics editor program. The scales are given in $\mathrm{mm}$. The specimen is provisionally deposited in the Entomological Museum, Universidad Del Valle, Santiago de Cali, Colombia (MUSENUV).

\section{RESULTS}

This species is part of group II (see Gonzalez et al. 2020), because it shares with the species of this group the character "hypandrium formed by a single sclerite" (Garcia Aldrete et al. 2011a, 2012), although it is variable in the characters of the phallosome. 


\section{DESCRIPTION OF NEW SPECIES}

Loneura garcialdretei $\mathbf{n}$. sp.

(Figs. 1-6)

http://zoobank.org/DF04DBC3-1EA2-4012B0E2-B21094047824

Diagnosis. Forewing with long submarginal brown spots at the end of each cell m, pterostigma with two hyaline areas and proximal/distal dark brown bands. Posterior lobes of the hypandrium distally widened, with parallel margins and each with short postero-lateral processes (Fig. 5); lateral endophallic sclerites $\mathrm{C}$-shaped, fused with the anterior sclerite (Fig. 6).

Male. Color. Body brown. Head pattern (Fig. 3), with a dark brown transversal band between the inner border of each compound eye, going through the ocellar triangle and in the direction to the epistomal sulcus. Vertex and occipucio light brown. Postoccipucio with brown cross band. Compound eyes black, ocelli hyaline, with dark ochre centripetal crescents. Anteclypeus, postclypeus and labrum dark brown. Genae and postgenae dark brown. Antennae: Scape dark brown; flagellomeres pale brown, cream apically. Maxillary palps: Mx1 creamy; Mx2-4 brown. Protorax cream, with small light brown pronotal stripe. Tergal lobes of meso- and metathorax brown, with small light brown spots. Mesothoracic pleura brown, with cream areas; metathoracic pleura cream, with small light brown areas. Legs pale brown, fore- and mid coxae brown, hindcoxa cream; trochanters cream; fore- femur, light brown, with two small brown spots; mid- and hind femora brown, cream apically; tibia and tarsi pale brown. Wings hyaline, with small brown spots, veins dark brown. Forewings mostly hyaline, veins with dark brown spots distally, at wing margin, with a submarginal brown band as long spots at the end of cell M, pterostigma hyaline, with proximal and distal brown bands. A brown band from $\mathrm{Cu} 1$ to distal end of $1 \mathrm{~A}$ (Fig. 1). Hindwings with brown spots distally on veins $\mathrm{M}$ at wing margin. Abdomen cream, with small ochre subcuticular spots; clunium dark brown. Hypandrium and phallosome brown. Epiproct and paraprocts light brown.

Morphology. Head (Fig. 3): H/MxW: 1.38; H/d: 3.25; IO/MxW: 0.73. Vertex almost at the same level of the upper border of the compound eyes. Outer cusp of lacinial tips broad, with six short denticles. Mx4/Mx2: 1.26. Forewings (Fig. 1): FW/W: 2.55. Pterostigma: lp/wp: 5.36, areola postica tall, almost as tall as long, rounded apically: al/ah: 1.26, $\mathrm{R} 2+3$ and R4 +5 sinuous, M six-branched, M3 - M6 forked. Hindwings (Fig. 2): HW/w: 2.82; M four-branched, sometimes three-branched. Hypandrium (Fig. 5), with lateral spicules in the middle distal part. Phallosome Y-shaped anteriorly, side struts slender; external parameres wide, bearing abundant pores, with thin and short teeth on distal outer margin (Fig. 6); two pairs of endophallic sclerites, anterior pair fused to lateral endophallic sclerite, C-shaped; mesal pair basally wide, bow shaped, distally hooked outwards (Fig. 6). Paraprocts (Fig. 4) robust, oval, with distal setal field and macrosetae as illustrated; sensory fields with 32 trichobothria on basal rosettes. Epiproct (Fig. 4) semioval, with short and long setae, with a field of microspicules anteriorly.

Measurements. FW: 4225, HW: 3025, F: 1057, T: 1875, t1: 810 t2: 85, t3: 132, ctt1: 26, f1: 690, f2: 585, f3: 540, f4: 490, f5: 367, f6: 345 , f7: 300, f8: 255, f9: 225 ,:, f10: 240, Mx4: 240, IO: 500, D: 404, d: 283, IO/d: 1.77 , PO: 0.70 .

Type locality. PERU. Cuzco. Kosñipata, Pillcopata, Sa-

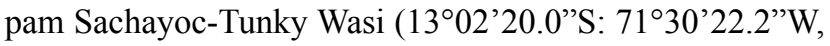
$1150 \mathrm{~m}), 27.28 . I X .2019$. N. Carrejo and R. Gonzalez. LED light trap in forest canopy. Holotype male. Paratypes: 1 male, same data as holotype. R. González \& N. Carrejo. LED light trap in forest canopy.

Etymology. This species is dedicated to Dr. Alfonso Neri Garcia Aldrete, in recognition to his important contributions to the taxonomy of the psocids and in particular of the Lachesillidae and Epipsocetae.

\section{PARTIAL KEY TO THE SPECIES GROUP II OF LONEURA}

(Modified from Gonzalez et al. 2020)

1. Hypandrium of one sclerite, resulting from the fusion of the proximal ends of the side sclerites to the central sclerite, this extended mesally on each side, with two posterior processes in the middle, variously shaped (Fig. 5) Group II ................................................. 2

1' Hypandrium of three sclerites, two small, elongate side sclerites flanking a large, central sclerite

................... Group I (see key in Gonzalez et al. 2020)

2. Forewings with a submarginal brown band, with segments arc-shaped, or with long spots only at the end of each cell m (Fig. 1) ............................................... 3

2'. Forewings without submarginal brown band as above, or without long spots at the end of cell $\mathrm{m}$, hyaline or with few spots ... (L. altaquerensis, L. farallonensis, L. gorgonaensis, L. insularis, L. monticola, L. nonuya, L. occidentalis and L. tatama) (see key in Gonzalez et al. 2020).

3. Hypandrium without deep medial incision that reaches near the base, with posterior processes widely separated, projected from postero-lateral corners of the hypandrium, not curved outwards ........ L. amazonica

3'. Hypandrium with deep medial incision that reaches near the base, with posterior processes not as above (Figs $37,43,91)$, postero-lateral process present or absent.

4. Posterior lobes of the hypandrium distally widened, with parallel margins and each with short latero-posterior processes, projected from postero-lateral corners (Fig. 5). Phallosome with lateral endophallic sclerites fused with the anterior sclerite, C- shaped (Fig. 6) .....

L. garcialdretei $\mathrm{n}$. sp.

4'. Posterior lobes of hypandrium not widened distally like the anterior or without latero-posterior processes in each. Phallosome with lateral endophallic sclerites variable .. (L. carijona, L. erwini, L. javierensis, L. ko- 
reguaje, L. misak, L. orucapu, L. zuluagai) (see key in Gonzalez et al. 2020).

\section{DISCUSSION}

This is the second species of Loneura described for Peru. The other species corresponds to L. erwini New \& Thornton (1988), collected in Madre de Dios, Rio Tambopata Res., 30 km (air) sw from Puerto Maldonado at 290 $\mathrm{m}$. Nevertheless, previous explorations have indicated that there are many species to discover and describe, which makes it a priority to carry out new explorations, especially in the Amazonian foothills of this country.

Due to the general form of the hypandrium, this species is related to the 16 species of Group II (Gonzalez et al. 2020). However, this form is also found in five of the species described in Euplocania. The fusion of the proximal ends of the lateral sclerites to the antero-lateral corners of the central sclerite, observed in the species of these two genera makes this a homoplasic character and therefore should be used carefully in morphological phylogenetic analyses. Based on the recent increase in the number of described species of Loneura sharing this character, it is convenient to redefine it, since a great variety of states is presented. The above, together with the observed variations (new character states) in the phallosome and wings could contribute to form different clades. In the particular case of L. garcialdretei $\mathrm{n}$. sp., the phallosome of this, as well as other species of the group, presents the bias for the anterior endophallic sclerites to fuse with the lateral ones, forming a single lateral structure. This is clearly shared with L. koreguaje, although the same pattern is also observed in $L$. $z u$ luagai, L. carijona and L. orucapu. Another character that they share is the shape of the mesal endophallic sclerite, these are usually wide basally and present the mesal sclerite processes wide proximally and tapered distally, this is observed in L. carijona, L. javierensis, L. koreguaje, L. orucapu and L. zuluagai. From the above, a phylogenetic analysis that includes all the species that have been described in the genus is required.

\section{ACKNOWLEDGMENTS}

We thank Departamento de Biología, Facultad de Ciencias Naturales y Exactas and Vicerrectoría de Investigaciones, Universidad del Valle, Santiago de Cali, Colombia, for research support. We also thank Florencio, Antonia and Angélica Amanki, from Sapan Sapayoc-Tunky Wasi (Pillcopata, Koñispata-Cuzco-Peru).

Recibido: 8 marzo 2020

Aceptado: 8 junio 2020

\section{LITERATURE CITED}

García Aldrete, A.N., R. González Obando \& N.S. Carrejo. 2011a. A new Loneura from Colombia, and Colombian records of L. mirandaensis García Aldrete, and Loneuroides venezolanus García Aldrete (Psocodea: 'Psocoptera': Ptiloneuridae). Dugesiana 18 (1): 35-37.

García Aldrete, A.N., R. González Obando and F.A. Sarria Sarria. 2011b. Three new species of Loneura (Psocodea: 'Psocoptera': Ptiloneuridae) from Gorgona Island, Cauca, Colombia, with a new infrageneric classification. Zootaxa 3050: 55-62. https://doi.org/10.11646/ zootaxa.3050.1.3

García Aldrete, A.N., J.A. Mendivil Nieto and R. González Obando. 2012. A pair of new sister species of Loneura (Psocodea, 'Psocoptera', Ptiloneuridae) from Valle del Cauca, Colombia, representing a new ingrageneric group. ZooKeys 168: 65-76. https://doi.org: 10.3897/ zookeys.168.2508.

García Aldrete, A.N., R. González Obando and N.S. Carrejo. 2020. On the genera Ptiloneura Enderlein, Loneura Navás, and Loneuroides García Aldrete (Psocodea: 'Psocoptera': Ptiloneuridae). Zootaxa, 4751 (2): 291309. https://doi.org/10.11646/zootaxa.4751.2.5.

González Obando, R., N.S. Carrejo, J.D. Panche and A.N. García Aldrete. 2020. The genus Loneura Navás (Insecta: Psocodea: 'Psocoptera': Ptiloneuridae) in Colombia, description of new species and key for identification. Zootaxa (in press)

González Obando, R., A.N. García Aldrete, and N.S. Carrejo. 2011. A new species of Steleops Enderlein, and a Colombian record of $S$. pulcher New (Psocodea: 'Psocoptera': Psocidae). Zootaxa, 2735, 23-27. https://doi. org/10.11646/zootaxa.2735.1.2

Mendivil Nieto, J.A., A.N. García Aldrete and R. González Obando. 2017. Seven new species of Loneura Navás (Insecta: Psocodea: 'Psocoptera': Ptiloneuridae) from Valle del Cauca, Colombia. Zootaxa 4227 (4): 495-523. https://doi.org/10.11646/zootaxa.4227.4.2

Moura Lima, D.M., A.M. Silva-Neto, A.N. García Aldrete and F. Bravo. 2019. Loneura Navás (Psocodea: Psocomorpha: Ptiloneuridae): new species from Brazil, and description of the female of Loneura maracaensis García Aldrete, with a checklist of all known species of the genus. Zootaxa 4576 (1): 179-186. https://doi. org/10.11646/zootaxa.4576.1.11

New, T.R. and I.W.B. Thornton. 1988. Epipsocetae (Psocoptera) from Peru. Studies on Neotropical Fauna and Environment 23 (4): 225-250. 


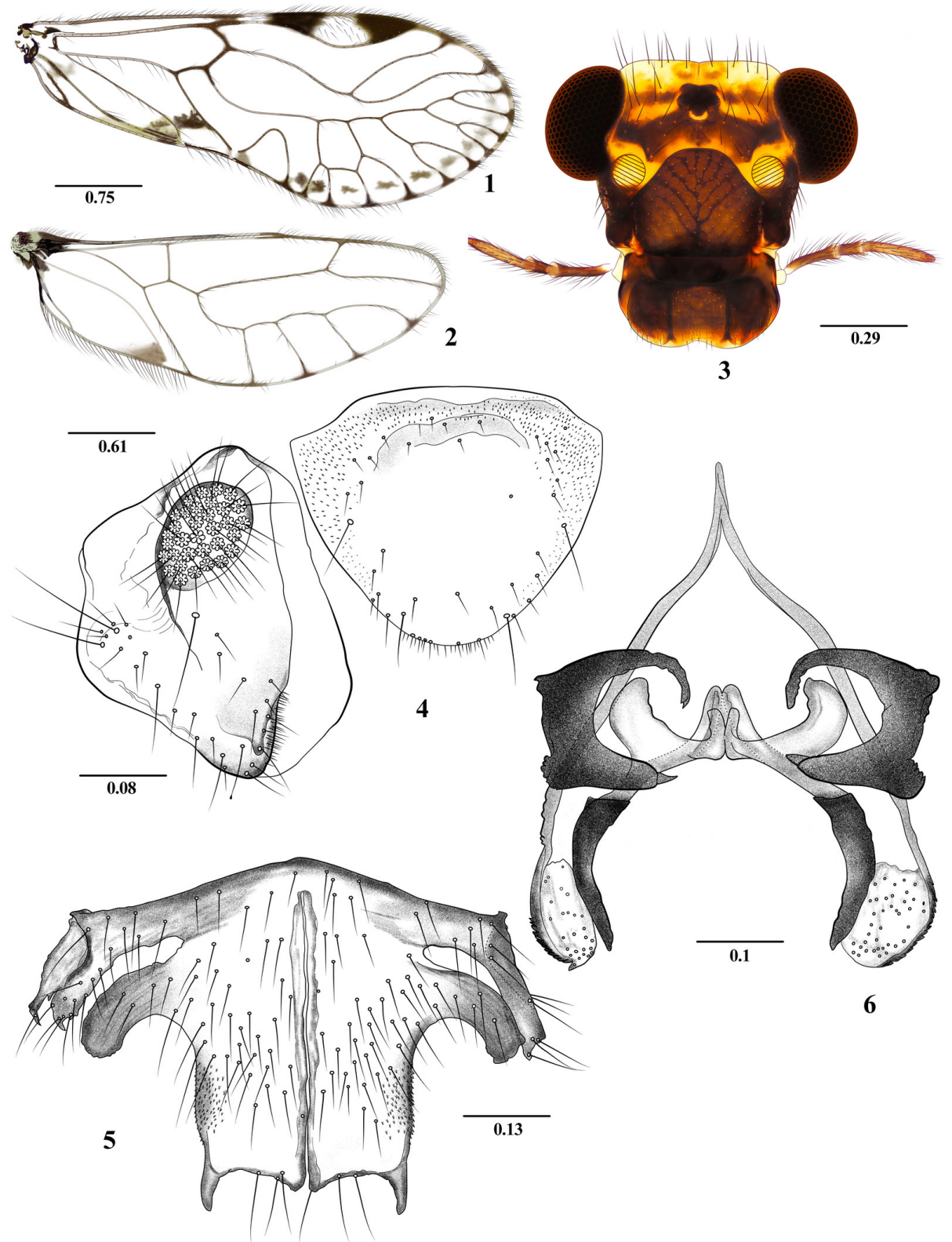

Figures 1-6. Loneura garcialdretei n. sp. Male. 1. Forewing. 2. Hindwing. 3. Front view of head. 4. Left paraproct and epiproct. 5. Hypandrium. 6. Phallosome. Scales in $\mathrm{mm}$. 